\title{
MENALAR SEL MEWAH DI LEMBAGA PEMASYARAKATAN
}

\author{
Y.A. Triana Ohoiwutun, Samsudi \\ Fakultas Hukum Universitas Jember \\ Jl. Kalimantan No. 37 Jember \\ anaohoiwutun@ymail.com
}

\begin{abstract}
The threat of imprisonment occupies a central position in a criminal stelsel, result in the imposition a lot of sanctions against the imprisonment of criminals. Advantages prison capacity, resulting to limited facilities provided to prisoners. Desire to get certain facilities in cell can be met only to rich people by did the dirty deed or bribe. To overcome these problems, can be taken through the prevention and control of criminal policy, that is by means of penal and a non-penal.
\end{abstract}

Keywords: a luxury cell, prison, bribe.

\begin{abstract}
Abstrak
Ancaman pidana penjara menempati posisi sentral dalam stelsel pidana, berakibat pada banyaknya penjatuhan sanksi pidana penjara terhadap pelaku tindak pidana, sehingga terjadi kelebihan kapasitas daya tampung lapas. Kelebihan daya tampung lapas, berakibat keterbatasan fasilitas yang disediakan untuk narapidana, sehingga terjadi permainan kotor atau suap. Fasilitas tertentu yang istimewa di dalam sel, hanya dapat dinikmati sebagian orang kaya. Untuk mengatasi permasalahan tersebut, dapat dilakukan pencegahan dan penanggulangan melalui kebijakan kriminal, yaitu melalui sarana penal dan non penal.
\end{abstract}

Kata kunci: sel mewah, penjara, suap.

\section{A. Pendahuluan}

Pasal 5 UU No. 12 Tahun 1995 tentang Pemasyarakatan (selanjutnya disebut UU Pemasyarakatan) menyebutkan, bahwa sistem pembinaan pemasyarakatan dilaksanakan berdasarkan asas: a. pengayoman; $b$. persamaan perlakuan dan pelayanan; c. pendidikan; d. pembimbingan; e. penghormatan harkat dan martabat manusia; f. kehilangan kemerdekaan merupakan satu-satunya penderitaan; dan g. terjaminnya hak untuk tetap berhubungan dengan keluarga dan orang-orang tertentu. Jaminan terlaksananya asas persamaan perlakuan dan pelayanan sebagaimana disebutkan di dalam Pasal 5 huruf b UU Pemasyarakatan, dalam praktek pelaksanaannya masih jauh panggang dari api, ketika Wakil Menteri Hukum dan HAM kala dijabat oleh Denny Indrayana melakukan inspeksi mendadak ke Lembaga Pemasyarakatan (selanjutnya disebut lapas)
Sukamiskin, Bandung dan Rutan Cipinang, Jakarta Timur. Dalam inspeksi mendadak tersebut ditemukan sejumlah perangkat alat elektronik, dan perangkat mewah lainnya. (www.metrotvnews.com, 2013) Fenomena sel dengan fasilitas yang tidak semestinya di lapas (selanjutnya disebut "sel mewah" di dalam penulisan ini), jelas hanya dapat dinikmati oleh orang-orang kaya, antara lain Arthalita Suryani alias Ayin (kasus korupsi), Lien Marita alias Aling (kasus narkoba), Darmawati Dareho (kasus korupsi), dan Ines Wulandari (kasus korupsi) (Barda Nawawi Arief, 2010). Sel sekelas hotel melati juga terjadi di Lapas Kelas 1 Surabaya PorongSidoarjo ketika petugas BNN dan Polda Jatim merazia tanggal 18 April 2016; ditemukan pula fasilitas alat-alat elektronik, tempat tidur spring bed dan beberapa kamar yang hanya dihuni satu orang narapidana (selanjutnya disebut napi) untuk kasus korupsi dan narkoba yang memang mendapatkan 
perlakuan khusus di dalam lapas. (http://daerah.sindonews.com, 2016). Di samping itu, ada pula penghuni lapas yang dapat memelihara kucing jenis anggora (http://www.infomenia.net, 2016)

Adanya sel mewah di dalam lapas sangatlah menarik untuk dicermati, karena keberadaannya pastilah berkorelasi dengan penyalahgunaan wewenang oleh oknum a parat penegak hukum. Dalam penyalahgunaan wewenang hampir selalu berkait dengan suap menyuap, adanya upeti, persembahan, uang sogokan, dan sebagainya. Bahasa asing mengenal banyak ungkapan yang berkonotasi dengan suap (bribe), yaitu pelicin (graft), sogok (embezzlement), atau penggelapan (fraud). Konotasi primer yang terbentuk dari istilah suap menyuap adalah adanya janji, iming-iming atau pemberian keuntungan yang tidak pantas oleh seseorang kepada pejabat atau pegawai negeri, langsung atau tidak langsung dengan maksud agar pegawai negeri atau pejabat tersebut berbuat atau tidak berbuat sesuai dengan tugasnya yang sah (Mudjahirin Thohir,2010).

Modus operandi kejahatan suap dapat melibatkan banyak pihak, termasuk di dalamnya penggunaan 'jasa profesi' mafia peradilan. Fenomena sel mewah, secara kasat mata jelas mencoreng institusi hukum, meskipun "hanya" melibatkan individuindividu atau oknum penegak hukum di lapas.

Sistem pembinaan pemasyarakatan menurut UU Pemasyarakatan menentukan adanya persamaan perlakuan dan pelayanan terhadap warga binaan. Sistem pembinaan pemasyarakatan terkait dengan pelaksanaan asas persamaan perlakuan dan pelayanan, tentunya tercederai dengan adanya sel mewah. Penerapan prinsip persamaan atau equality before the law dalam pelaksanaan sanksi pidana penjara oleh aparat penegak hukum merupakan kewenangan aparat lapas. Pelaksanaan pidana penjara yang menggunakan sistem pemasyarakatan memang merupakan sub sistem dari satu rangkaian penegakan hukum pidana atau bagian dari rangkaian sistem peradilan pidana (criminal justice system) di Indonesia. Pelaksanaan sanksi pidana penjara melalui sistem pemasyarakatan sebagai akhir dari sebuah sistem peradilan pidana, pada hakekatnya diharapkan dapat mencapai tujuan pemidanaan.

Keberadaan sel dengan fasilitas istimewa mengindikasikan potret penegakan hukum yang jauh panggang dari api, khususnya dalam mencapai hakekat tujuan pemidanaan. Eksistensi pidana penjara itu sendiri pada kenyataannya masih debatable, bahkan ICOPA (International Conference on Prison Abolitian) memberikan kritik ekstrem dengan menghendaki hapusnya sama sekali pidana penjara (Barda Nawawi Arief, 2013); di samping itu, Hazairin menyatakan, bahwa masyarakat tanpa penjara merupakan suatu ideal yang tinggi mutu filsafat dan keuntungannya, baik dilihat secara spiritual maupun secara materiel (Hazairin, 1981). Terlepas dari adanya perdebatan mengenai eksistensi pidana penjara, penulis tertarik mengangkat permasalahan keberadaan sel mewah atau sel dengan fasilitas yang tidak semestinya di lapas. Fenomena sel dengan fasilitas yang menyimpang/melanggar aturan pada hakekatnya tidak dapat dilepaskan dari bekerjanya sebuah sistem di dalam criminal justice system. Oleh karena itu, menalar dari adanya sel dengan fasilitas istimewa di dalam lapas, penulis merumuskan permasalahan utama dalam penulisan ini adalah: mengapa terjadi fenomena sel mewah di dalam lapas?

\section{B. Pembahasan}

Hukum yang paling tua hanyalah hukum pidana (Hans Kelsen, 2015). Sanksi hukum memiliki karakter sebagai tindakan paksa (Hans Kelsen, 2015), dan pidana penjara adalah sanksi perampasan kemerdekaan; meskipun ada upaya-upaya untuk meniadakannya, namun faktanya sampai saat ini ancaman pidana penjara menempati posisi sentral dalam stelsel pidana. Menurut Barda Nawawi Arief, di antara berbagai jenis pidana pokok, pidana penjara merupakan jenis sanksi pidana yang paling banyak ditetapkan dalam produk perundang-undangan selama ini (Barda Nawawi Arief, 2010). Ancaman sanksi pidana penjara berada pada posisi sentral dalam sistem sanksi di dalam hukum pidana (Dari seluruh ketentuan KUHP), dan undangundang administrasi menempatkan ancaman sanksi pidana penjara (dan juga sanksi pidana kurungan) dalam upaya mengukuhkan norma 
administrasi yang diaturnya.

Penjara merupakan satu-satunya tempat pelaksanaan sanksi perampasan kemerdekaan, baik berupa sanksi pidana penjara maupun kurungan. Posisi ancaman sanksi perampasan kemerdekaan sebagai sanksi utama di dalam berbagai macam formulasi undang-undang dalam law enforcement-nya berkorelasi dengan banyaknya penjatuhan sanksi pidana penjara maupun sanksi pidana kurungan.

Banyaknya jenis ancaman sanksi perampasan kemerdekaan dalam formulasi peraturan perundangan, termasuk peraturan daerah yang mengancam sanksi pidana kurungan, turut berkontribusi pada semakin banyaknya jumlah napi sebagai warga binaan di lapas. Penempatan ancaman perampasan kemerdekaan dalam mengukuhkan norma yang diaturnya, secara tidak langsung berpengaruh secara signifikan pada terjadinya kelebihan kapasitas (over capacity/over crowding) daya tampung lapas dalam pelaksanaan putusan pidana penjara. (Lapas dan rutan, 2010) Kelebihan daya tampung lapas, berakibat pada semakin terbatas atau bahkan secara ekstrim kekurangan fasilitas umum maupun fasilitas khusus bagi napi di dalam lapas. Kondisi over capacity/over crowding yang memicu keinginan orangorang tertentu untuk mendapatkan fasilitas yang diinginkannya. Keinginan untuk memenuhi kebutuhan fasilitas pribadi yang tidak seharusnya tersedia di dalam lapas, merupakan pilihan rasional yang dilakukan oleh napi yang kaya dan beruntung secara finansial. Keuntungan finansial yang dimiliki oleh napi tertentu memungkinkan dilakukannya tindakan curang demi memenuhi keinginan mendapatkan fasilitas yang tidak seharusnya tersedia di dalam sel lapas. PP Nomor 32 Tahun 1999 tentang Syarat dan Tata Cara Pelaksanaan Warga Binaan Pemasyarakatan Pasal 28 menentukan, bahwa ayat: (1) setiap narapidana dan anak didik pemasyarakatan yang berkeinginan membawa dan mendapat bahan bacaan atau informasi dari media massa dari luar lapas, harus mendapat izin dari kepala lapas; (2) setiap lapas menyediakan sekurang-kurangnya 1 (satu) buah pesawat televisi, 1 (satu) buah radio penerima, dan media elektronik lain yang tidak bertentangan dengan peraturan perundang-undangan yang berlaku; (3) narapidana dan anak didik pemasyarakatan dilarang membawa pesawat televisi dan radio atau media elektronik yang lain ke dalam lapas untuk kepentingan pribadi.

Merujuk pada PP Nomor 32 Tahun 1999 Pasal 28 khususnya ayat (3), keberadaan sejumlah perangkat elektronik, dan perangkat mewah lainnya di dalam lapas yang hanya dapat dinikmati oleh mereka yang kaya raya nota bene terpidana kasus korupi dan narkoba, jelas merupakan pelanggaran, bahkan menjadi sebuah ironi. Fenomena ini pastilah berkorelasi dengan penyalahgunaan wewenang oleh oknum petugas lapas berkait dengan kolusi yang berupa uang pelicin atau sogokan atau suap.

Adanya kolusi yang berupa uang pelicin atau sogokan atau suap, hampir selalu berhubungan dengan adanya kepentingan timbal balik di antara pemberi suap dengan penerima suap. Hubungan kepentingan yang bersifat timbal balik adalah penyebab terjadinya kejahatan penyuapan. Unsur kepentingan keinginan napi menikmati fasilitas mewah dan modern di dalam lapas yang dijadikan alasan untuk menyuap petugas lapas; sedangkan penerima suap adalah pihak yang memiliki otoritas untuk memenuhi atau menolak kepentingan pemberi suap. Kejahatan suap-menyuap sebagai kejahatan transaksional, bersifat timbal balik atau resiprosikal; dan transaksi hanya bisa terjadi apabila kedua belah pihak setuju tentang besaran uangnya, keputusan yang hendak dibengkokkan, dan bentuk transaksinya (Mudjahirin Thohir, 2010).

Fenomena sel dengan fasilitas istimewa di dalam lapas, jelas terkait dengan kejahatan transaksional yang berhubungan dengan penyalahgunaan wewenang. Dalam pe n y a l a g g n a a n w e w e n $\mathrm{g}$ merepresentasikan praktek buruk pelaksanaan suatu tugas profesi yang dapat dikategorikan sebagai malpraktek profesi petugas lapas. Dari kacamata Sutherland malpraktek pengemban profesi hukum termasuk dalam kriteria white collar crime, yang unsur-unsurnya meliputi: suatu kejahatan yang dilakukan oleh orang yang 
terhormat sehubungan dengan jabatannya, dan unsur terakhir menurut Sutherland adalah violation of trust (pelanggaran kepercayaan) (C.Maya Indah S, 2011). Profesi hukum memiliki kekuasaan yang luar biasa dan bisa memegang nasib dan kepercayaan, baik private trust (kepercayaan pribadi), maupun public trust (kepercayaan publik) (C.Maya Indah S, 2011). Fenomena sel mewah di dalam lapas mengindikasikan adanya black market of justice (pasar gelap keadilan) yang berpotensi merusak private trust (kepercayaan pribadi), maupun public trust (kepercayaan publik).

Pelaksanaan sanksi pidana penjara melalui sistem pemasyarakatan sebagai akhir dari sebuah sistem peradilan pidana, diharapkan dapat mencapai tujuan pemidanaan, sebagaimana ditentukan di dalam Pasal 2 UU Pemasyarakatan, bahwa: sistem pemasyarakatan diselenggarakan dalam rangka membentuk warga binaan pemasyarakatan agar menjadi manusia seutuhnya, menyadari kesalahan, memperbaiki diri, dan tidak mengulangi tindak pidana sehingga dapat diterima kembali oleh lingkungan masyarakat, dapat aktif berperan dalam pembangunan, dan dapat hidup secara wajar sebagai warga yang baik dan bertanggung jawab; kemudian Penjelasan Atas PP Nomor 32 Tahun 1999 menyatakan, bahwa sistem pemasyarakatan bertujuan untuk mengembalikan warga binaan pemasyarakatan sebagai warga yang baik dan untuk melindungi masyarakat terhadap kemungkinan diulanginya tindak pidana oleh warga binaan serta merupakan penerapan dan bagian yang tak terpisahkan dari nilai-nilai yang terkandung dalam Pancasila.

Merujuk pada sistem pemasyarakatan sebagaimana diamanatkan Pasal 2 UU Pemasyarakatan maupun PP Nomor 32 Tahun 1999, menuntut kinerja petugas lapas yang profesional, karena meskipun berbeda pada wewenang dan pengorganisasiannya, posisi petugas lapas menempati bagian akhir dari suatu proses di dalam sistem peradilan pidana. Laksana pola atletik lari estafet bagi semua pelari merupakan satu kesatuan tugas lari kencang membawa tongkat estafet untuk keberhasilan meraih medali kemenangan
(Bambang Poernomo, 1993), demikianlah, sebagai akhir sebuah sistem peradilan pidana, keberhasilan dalam meraih tujuan penjatuhan sanksi pidana penjara, tuntutan aparat petugas lapas yang profesional bersifat conditio sine qua non, tidak dapat dipisahkan antara profesional petugas lapas dengan tujuan pemidanaan.

Fenomena sel dengan fasilitas istimewa di dalam lapas yang hanya dapat dinikmati oleh napi tertentu jelas bertentangan dengan UU Pemasyarakatan Pasal 5 huruf b, yaitu persamaan perlakuan dan pelayanan, yang dalam penjelasannya ditegaskan bahwa maksud dari "persamaan perlakuan dan pelayanan" adalah pemberian perlakuan dan pelayanan yang sama kepada warga binaan pemasyarakatan tanpa membeda-bedakan orang. Adanya sel mewah di dalam lapas yang hanya dapat dinikmati napi tertentu, dapat dikatakan merupakan pelanggaran hak asasi bagi sesama napi untuk diperlakukan sama dan pengingkaran terhadap persamaan di muka hukum (equality before the law) sebagaimana diamanatkan dalam negara hukum.

"Persamaan perlakuan dan pelayanan" sebagaimana dinyatakan di dalam Penjelasan Pasal 5 huruf b UU Pemasyarakatan adalah pemberian perlakuan dan pelayanan yang sama kepada Warga Binaan Pemasyarakatan tanpa membeda-bedakan orang. Konsep persamaan perlakuan mengandung makna bahwa pelayanan dalam rangka pemasyarakatan dilakukan tanpa membedabedakan orang adalah identik dengan prinsip equality before the law. Persamaan di muka hukum dan terjaminnya hak asasi manusia merupakan salah satu perwujudan dari pelaksanaan negara hukum, sebagaimana diamanatkan Pasal 1 Ayat (3) UUD 1945 Amandemen ke-4 yang menentukan, bahwa Negara Indonesia adalah negara hukum (Mahfud MD, 2006). Menurut A.V. Dicey, rule of law dirumuskan menjadi tiga gagasan, yaitu: 1) supremasi hukum, tidak boleh ada kesewenang-wenangan, orang boleh dihukum bila melanggar hukum, 2) adanya kesamaan di depan hukum, dan 3) terjaminnya hak asasi manusia oleh undangundang dan putusan pengadilan (Satjipto Rahardjo, 2009). Lebih lanjut Pasal 28 D Ayat 
(1) UUD 1945 Amandemen ke-4 menentukan, bahwa setiap orang berhak atas pengakuan, jaminan, perlindungan, dan kepastian hukum yang adil serta perlakuan yang sama di hadapan hukum. Fenomena sel mewah di dalam lapas yang hanya dapat dinikmati oleh orang-orang kaya, apabila mengacu pada UUD 1945 Amandemen ke-4 Pasal 1 Ayat (3) dan Pasal 28 D Ayat (1), jelas mencederai prinsip equality before the law, dan prinsip keadilan di dalam sebuah negara hukum.

Setiap hukum yang dilaksanakan ada tuntutan untuk keadilan, maka hukum tanpa keadilan akan sia-sia sehingga hukum tidak lagi berharga di hadapan masyarakat (H.M. Agus Santoso, 2014). Keberadaan sel mewah yang hanya dinikmati oleh orang kaya, dapat dikaji dari perspektif teori keadilan sebagaimana dikemukakan oleh John Rawls. Keadilan menurut Rawls dimaknai sebagai "kesetaraan" (justice as fairness), artinya tak seorangpun diperbolehkan mendominasi pilihan atau memanfaatkan kesempatan yang tidak adil seperti kelebihan dari anugerah alamiah atau posisi sosialnya, karena prinsip keadilan merupakan pilihan yang setara (Karen Lebacqz, 2015). Keadilan sebagai kesetaraan, secara kasat mata tidak memihak pada napi yang miskin dengan strata sosial lemah atau bahkan rendah, menikmati sel lapas dengan fasilitas mewah adalah kesempatan yang hanya dapat dinikmati oleh napi kaya. Posisi ketidaksetaraan terjadi antara napi kaya yang mampu menyuap dengan napi yang tidak mampu menyuap. Posisi ketidaksetaraan di dalam menjalani sanksi pidana penjara adalah ketimpangan dalam memperoleh keadilan atau bahkan merupakan ketidakadilan. Keberadaan sel mewah di lapas bersifat diskriminatif dan mengindikasikan ketidaksetaraan berlakunya hukum. Hukum hanyalah tajam ke bawah, tetapi berpihak pada yang kuat, kaya dan berkedudukan tertentu di masyarakat.

Keberadaan sel mewah di dalam lapas pada hakikatnya bersifat kriminogen karena berpotensi menjadi sumber kejahatan lain. Penjatuhan sanksi pidana penjara terhadap napi karena melakukan suatu kejahatan, dan perbuatan menyuap oknum petugas lapas untuk mendapatkan fasilitas sel mewah merupakan kejahatan tersendiri. Di samping itu, "kenikmatan sel mewah" di dalam lapas dapat memicu kemungkinan terjadinya pengulangan kejahatan selepas menjalani sanksi pidana penjara. Oleh karena itu, fenomena sel mewah di dalam lapas haruslah disikapi dan dipandang secara integral, karena keberadaannya tidaklah berdiri sendiri, justru implikasinya yang mengandung banyak dimensi yang patut diwaspadai.

Fenomena sel mewah secara potensial bersifat viktimogin, karena dapat merugikan berbagai dimensi kepentingan dari yang kecil sampai dengan yang besar, kepentingan sesama napi dan kepentingan kepercayaan publik (public trust) pada penegakan hukum di lapas. Pengingkaran dan pengkhianatan terhadap asas persamaan di muka hukum (equality before the law) pada hakikatnya merupakan implikasi tersendiri dari keberadaan sel mewah di dalam lapas. Diskriminasi terhadap napi yang tidak mampu menyuap jelas terjadi, bahkan dalam skala luas berpotensi terjadinya residivis atau kecenderungan melakukan kejahatan di kalangan orang kaya yang mampu 'membeli' selmewah.

Permainan kotor/curang oleh oknum petugas lapas merupakan pelanggaran atas hukum pidana. Permainan kotor yang berkait dengan suap, uang pelicin atau pemberian bentuk lain, hanya dapat diberikan oleh mereka yang kaya raya. Di sisi lain, pungutan liar merupakan fenomena tersendiri untuk mendapatkan fasilitas tertentu di dalam lapas. Perpres Nomor 87 Tahun 2016 tentang Satuan Tugas Sapu Bersih Pungutan Liar (lazim disebut Satgas Saber Pungli) ditetapkan tanggal 20 Oktober 2016 diharapkan dapat memberantas segala macam bentuk praktik pungutan liar maupun suap di segala lini instansi pemerintah. Satgas Saber Pungli bertugas melaksanakan pemberantasan pungutan liar secara efektif dan efisien dengan mengoptimalkan pemanfaatan personil, satuan kerja, dan sarana prasarana, baik yang berada di kementerian/lembaga maupun pemerintah daerah. Satgas Saber Pungli, yang bertugas dalam pemberantasan pungli, suap, penyelundupan, over capacity lapas, pelayanan hukum, serta pelayanan 
S I M, S T N K d a n B P K B (http://nasional.news.viva.co.id/, 2016), kiranya dapat diberdayakan di dalam memberantas keberadaan sel mewah. Fungsi hukum pidana yang bersifat ultimum remedium, patutlah diaplikasikan dalam memberantas fenomena sel mewah di lapas. Formulasi pencegahan tindak pidana suap ditentukan di dalam UU No. 20 Tahun 2001 tentang Perubahan Atas UU No. 31 Tahun 1999 tentang Pemberantasan Tindak Pidana Korupsi. Suap diartikan sebagai gratifikasi dalam Penjelasan Pasal 12 B UU No. 20 Tahun 2001 telah diperluas cakupan ruang lingkupnya, meliputi pemberian uang, barang, rabat (discount), komisi, pinjaman tanpa bunga, tiket perjalanan, fasilitas penginapan, perjalanan wisata, pengobatan cuma-cuma dan fasilitas lainnya. Gratifikasi tersebut diterima, baik di dalam maupun di luar negeri, dan dilakukan dengan sarana elektronik atau tanpa sarana elektronik. Di samping itu, kriminalisasi suap sebelumnya juga ditentukan di dalam UU No. 11 Tahun 1980 tentang Tindak Pidana Suap. Oleh karena itu, efektivitas bekerjanya Satgas Saber Pungli secara tegas, terpadu dan efisien telah didukung dengan perangkat formulasi tentang suap atau gratifikasi. Penerapan fungsi ultimum remidium di dalam hukum pidana yang sanksinya kejam dapat didayagunakan dalam mengatasi permasalahan sel mewah di dalam lapas.

\section{Simpulan}

Fenomena sel mewah di dalam lapas tidak dapat dilepaskan dari adanya penyalahgunaan wewenang yang terkait dengan adanya perbuatan suap menyuap, dan implikasinya bertentangan dengan prinsip persamaan (equality before the law) dan prinsip keadilan dalam negara hukum. Formulasi ancaman sanksi perampasan kemerdekaan di dalam peraturan perundangan, berpengaruh secara signifikan terjadinya kelebihan kapasitas (over capacity/over crowding) daya tampung lapas yang turut memicu adanya sel mewah di dalam lapas.

Fenomena sel mewah bersifat kompleks, bukan merupakan permasalahan hukum pidana semata, namun juga berhubungan dengan masalah sosial, ekonomi, politik, budaya, moral dan administrasi yang berada di luar ranah hukum pidana. Oleh karena itu, pendekatan penal perlu ditunjang dengan pendekatan non penal yang bersifat preventif antisipatif justru menempati posisi strategis dalam upaya mengatasi permasalahan sel mewah di dalam lapas.

\section{DAFTAR PUSTAKA}

\section{Buku}

Hazairin, 1981, Tujuh Serangkai Tentang Hukum, Bandung: Bina Aksara.

Kelsen, Hans, (Penerjemah Raisul Muttaqien), 2015, Teori Umum tentang Hukum dan Negara, Bandung: Nusa Media.

Lebacqz, Karen, (Terjemahan: Yudi Santoso), 2015, Teori-teori Keadilan Six Theories of Justice, Bandung: Nusa Media.

MD, Mahfud, 2006, Membangun Politik Hukum, Menegakkan Konstitusi, Jakarta: LP3ES.

Nawawi Arief, Barda, 2010, Kebijakan Legislatif Dalam Penanggulangan Kejahatan dengan Pidana Penjara, Yogyakarta: Genta Publishing.

Nawawi Arief, Barda, 2013, Kapita Selekta Hukum Pidana Cetakan ke-3, Bandung: Citra Aditya Bakti.

Poernomo, Bambang, 1993, Pola Dasar Teori-Asas Umum Hukum Acara Pidana dan Penegakan Hukum Pidana, Yogyakarta: Liberty.

Rahardjo, Satjipto, 2009, Lapisan-lapisan Dalam Studi Hukum, Malang: Bayu Media.

Santoso, H.M. Agus, 2014, Hukum, Moral, \& Keadilan Sebuah kajian Filsafat, Jakarta: Kencana.

Jurnal:

C.Maya Indah S., "Pemberantasan Mafia Peradilan Menuju Reformasi Hukum di Indonesia", Jurnal Masalah Masalah Hukum, Jilid 40 No. 1 Maret 2011.

Makalah:

Nawawi Arief, Barda, Tindak Pidana Suap 
dan Mafia Peradilan Ditinjau Dari Aspek Politik Hukum Nasional, Makalah Seminar Nasional, Suap, Mafia Peradilan, Penegakan Hukum dan Pembaharuan Hukum Pidana Kerjasama antara Fakultas Hukum Universitas Diponegoro dan Komisi Yudisial Republik Indonesia, Semarang 10 Maret 2010.

Nawawi Arief, Barda, Beberapa Alternatif Pidana Penjara, Makalah Seminar Negara Tanpa Penjara IAIN Walisongo Semarang, 1 April 2010.

Thohir, Mudjahirin, Suap Dalam Ranah Masyarakat Indonesia Perspektif Sosial Budaya, Makalah Seminar Nasional, Suap, Mafia Peradilan, Penegakan Hukum dan Pembaharuan Hukum Pidana Kerjasama antara Fakultas Hukum Universitas Diponegoro dan Komisi Yudisial Republik Indonesia, Semarang 10 Maret 2010.

\section{Peraturan Perundang-undangan:}

UUD 1945 Amandemen ke-4.

UU No. 11 Tahun 1980 tentang Tindak Pidana Suap.

UU No. 12 Tahun 1995 tentang Pemasyarakatan.

UU No. 20 Tahun 2001 tentang Perubahan Atas UU No. 31 Tahun 1999 tentang Pemberantasan Tindak Pidana Korupsi.

PP Nomor 32 Tahun 1999 tentang Syarat dan Tata Cara Pelaksanaan Warga Binaan Pemasyarakatan.

Perpres Nomor 87 Tahun 2016 tentang Satuan Tugas Sapu Bersih Pungutan Liar

\section{Internet:}

http://www.metrotvnews.com/videoprogram /detail/2013/05/20/17286/733/Sidak\% 20Wamenkumham\%20ke \%20Penjara \%20/Metro\%20Malam diakses $25 \mathrm{Mei}$ 2013.

http://www.poskotanews.com/2013/05/21/st op-fasilitas-mewah-terpidanakoruptor/diakses 25 Mei 2013.

http://daerah.sindonews.com/read/1102143/ 23/sel-mewah-lapas-porong-layaknyahotel-kelas-melati-1461009398 diakses 1 Desember 2016.

http://www.infomenia.net/2016/04/wow-sel- mewah-koruptor-di-lapas.html diakses 1 Desember 2016.

http://nasional.news.viva.co.id/news/read/83 4412-korupsi-tak-masuk-target-satgassaber-pungli diakses 7 Desember 2016. 